\title{
Bazı silajlık mısır çeşitlerinde (Zea mays L.) verim ve kalite özelliklerinin belirlenmesi*
}

\author{
Nuri YILMAZ ${ }^{\circledR 1}$, Osman AKMAN ${ }^{\circledR 2}$, Özlem ÖNAL AŞCI ${ }^{\circledR} 1$
}

*Yüksek Lisans çalışmasından alınmıştır.

${ }^{1}$ Ordu Üniversitesi Ziraat Fakültesi Tarla Bitkileri Bölümü, Ordu

2Tarım ve Orman Bakanlığı Çarșamba İlçe Müdürlüğü, Samsun

Alınış tarihi: 4 Şubat 2020, Kabul tarihi: 5 Haziran 2020

Sorumlu yazar: Nuri YILMAZ, e-posta: y_nuri@hotmail.com

\section{$\ddot{0} \mathbf{z}$}

Bu çalışma, bazı silajlık mısır çeşitlerinde (Zea mays L.) verim ve kalite özelliklerinin belirlenmesi amacıyla 2018 yılında Samsun Çarşamba ekolojik koşullarında sulamalı olarak yürütülmüştür. Denemede 10 mısır çeșidi (RX-9292, DKC- 955, 30 B 74, 36 K 61, Hido, 72 May 80, Otello, Reserve, Aga, Samada-07) Tesadüf Blokları planına göre 3 tekrarlamalı olarak ekilmiștir. Araştırma sonucunda yeşil ot verimi 7 242.7-11 $077.0 \mathrm{~kg} \mathrm{da} \mathrm{d}^{-1}$, sap/bitki oranı \% 34.9-47.5, kuru madde verimi 3 017.0-3 $525.7 \mathrm{~kg} \quad \mathrm{da}^{-1}$ arasında değişmiştir. Kalite özelliklerinden ham protein oranı \% 5.01-9.48 arasında değişmiş ve en yüksek protein oranı 72 MAY 80 (\% 9.48) ve $36 \mathrm{~K} 61$ (\% 8.65) çeşitlerinde, NDF oranı \% 42.40-56.00 arasında değişmiş ve en yüksek NDF oranı 30 B 74 (\% 56.00) ve DKC-955 (\% 53.30) çeşitlerinde, ADF oranı \% 29.00-39.17 arasında değişmiş ve en yüksek ADF oranı DKC-955 (\% 39.17) ve AGA (\% 37.47) çeşitlerinde belirlenmiştir.

Anahtar Kelimeler: Silajlık Mısır, Kalite Özellikleri, NDF, ADF, Protein

\section{Determination of yield and quality characteristics of some silage maize (Zea mays $\mathrm{L}$.) varieties}

\section{Abstract}

This study was conducted to determine the yield and quality characteristics of some silage maize (Zea mays L.) varieties grown at Çarşamba Samsun, in 2018. The experiment was laid out using randomized blocks design with 3 replications of 10 different maize varieties (RX-9292, DKC- 955, 30 B 74, 36 K 61, Hido, 72 May 80, Otello, Reserve, Aga, Samada-07). As a result, the green herb yield was between 7242.7 and $11077.0 \mathrm{~kg} \mathrm{da}^{-1}$, stem/plant rate was between 34.9 and $47.5 \%$, dry matter yield was between 3017.0 and $3525.7 \mathrm{~kg} \mathrm{da}^{-1}$. Crude protein contens of the cultivars were between 5.01 and $9.48 \%$ and the highest protein content was determined in cv. 72 MAY 80 $(9.48 \%)$ and $36 \mathrm{~K} 61(8.65 \%)$. NDF contents ranged from 42.40 to $56.00 \%$ and the highest NDF content was calculated in cv. 30 B 74 (56.00\%) and DKC-955 (53.30\%), ADF content was between 29.00 and 39.17 $\%$ and the highest ADF content was in DKC-955 (39.17\%) and AGA (37.47 \%) varieties.

Keywords: Silage Maize, Quality Characteristics, NDF, ADF, Protein

\section{Giriş}

Mısır, Dünyada Antartika kıtası haricinde, hemen hemen her iklim kuşağında tarımı yapılabilen bir sıcak iklim tahılıdır.

Türkiye'de mısır üretimi, Karadeniz ve Marmara Bölgeleri'nde 1950’li yllarda daha yoğunken, 1980'lerden sonra yoğunluk Ege ve Akdeniz Bölgeleri'ne geçmiştir. Günümüzde ise Akdeniz, Güneydoğu Anadolu ve İç Anadolu Bölgesi toplam üretimin yaklaşık \% 67'sini sağlamaktadır. Ülkemizde hayvan beslenmesinde misır silajı kullanımı yaygınlaşmakta ve buna paralel olarak silaj amacı ile 
mısır ekimi artmaktadır. Hayvancılık için önemli bir kaba yem kaynağı olan silajlık mısır ekiminde ise 2017 yılına göre 2018 yılında \% 4-5 lik bir artış söz konusudur. Ülkemizde ekilen toplam misır ekim alanının \% 75'i danelik,\% 25'i ise slajlık mısır olarak üretimi yapılmaktadır (Anonim, 2018).

1930 yılında misır ekim alanı 379 bin hektar, verimi 1.01 ton ha-1 iken, 2000 yllında ekim alanı 1.5 kat, verim ise yaklaşık 4 kat artış göstermiştir. 2014 yılından sonra sulu koşullarda yetiştiriciliğinin yaygınlaştırılmasıyla Türkiye mısır verimi 9 ton ha-1' geçmiştir.

Ülkemizde mısır en fazla (\% 70 oranında) hayvan yemi ve yem ham maddesi olarak, büyükbaşküçükbaş hayvan yemlerinde ve kanatlı hayvan sektöründe, kullanılmaktadır. Bunun dışında nişasta, yağ ve etanol üretiminde kullanılmaktadır (Çevik, 2012).

Son yıllarda misırın, birim alandan elde edilen veriminin fazla olması, silaj yapımına ugunluğu ve mısır silajının besleme değerinin yüksek ve kaliteli olması gibi nedenlerden dolayı silaj üretimi amacıyla ekim alanı artmıştır.

Mısır üretiminin artmasında, çeşitler, tarımsal mekanizasyon, verim, yetiştirme teknikleri, dayanıklılık, ekim zamanı, maliyet ve yem kalitesi gibi faktörler etkili olmuştur (Phipps ve Wilkinson, 1985; Kılıç, 1986; Çete ve Sarıcan, 1998).
Buna rağmen ülkemizde silaj üretimi için tescil edilmiş mısır çeşitleri yeterli sayıda değildir. Ülkemizde ticari üretim izni olan mısır çeșitleri daha çok tane amaçlı kullanılan çeşitler içindir. Ancak bu tescilli tane misır çeşitleri silajlık olarakta kullanılmaktadırlar.

Silaj üretimi amacıyla yetiştirildiği bölgenin iklim şartları göz önünde tutularak orta erkenci çeşitler (FAO olum grubuna göre) tercih edilmelidir. Çeşitlerin hasat zamanında koçan bağlamış olması verim ve kalite açısından önem arzetmektedir. Silajın kalitesi bakımından yeni silajlık mısır çeşitlerinin geliştirilmesi ve üretime sunulması gerekmektedir.

$\mathrm{Bu}$ çalışmanın amacl; Samsun şartlarında yetiştirilebilecek bazı silajlık mısır çeşitlerinin verim ve kalite özelliklerinin belirlenmesidir.

\section{Materyal ve Yöntem \\ Materyal}

Araştırmada özel tohumluk firmalarından sağlanan 10 misır çeşidi (RX-9292, DKC- 955, 30 B 74, 36 K 61, Hido, 72 May 80, Otello, Reserve, Aga, Samada-07) kullanılmış olup, çeşitlerin temin edildiği kuruluşlar, olum süreleri ve FAO olum grupları Çizelge 1'de gösterilmiştir.

$\mathrm{Bu}$ çalışma Karadeniz Tarımsal Araştırma Enstitüsü (KTAE)'nün Çarşamba Ambarköprü deneme istasyonunda, drenaj sorunu bulunmayan arazide 2018 yılında yürütülmüştür.

Çizelge 1. Araştırmada kullanılan çeşitler, temin edildiği kuruluşlar, olum süreleri ve FAO olum grupları

\begin{tabular}{ccccc}
\hline Sira no & Çeşit & Temin edilen kuruluş & Olum süresi (gün) & FAO olum grubu \\
\hline 1 & RX-9292 & May-Agro & 130 & FAO 700 (çok geç) \\
2 & DKC-955 & Dekalb & $110-115$ & FAO 800 (çok geç) \\
3 & 30 B 74 & Pioneer Toh. & 120 & FAO 700 (çok geç) \\
4 & 30 K 61 & Pioneer Toh. & $90-100$ & FAO 550 (orta) \\
5 & Hido & May-Agro & $100-110$ & FAO 700 (çok geç) \\
6 & May 80 & May-Agro & $100-110$ & FAO 700 (çok geç) \\
7 & Otello & Poltar Tarım & $115-120$ & FAO 600 (geç) \\
8 & Reserve & Syngenta Tarım & $100-105$ & FAO 700 (çok geç \\
9 & Aga & Misır AE\&Batı Akdeniz AEM & 135 & FAO 720 (çok geç) \\
10 & Samada-07 & Misır AE\&Karadeniz TAEM & 130 & FAO 700 (çok geç) \\
\hline
\end{tabular}

Araştırma alanından ekim öncesi alınan toprak örnekleri KTAE Toprak, Bitki, Su Analiz Laboratuvarında analiz edilmiştir. Sonuçlar deneme alanı toprağının killi tınlı (İşba \% 66.00), hafiif alkali (pH: 7.86), tuzsuz (Toplam tuz: 0.05), orta kireçli $\left(\mathrm{CaCO}_{3} \%\right.$ : 6.76), fosfor miktarının çok az $\left(\mathrm{P}_{2} \mathrm{O}_{5}: 2.52\right.$ $\mathrm{kg} \mathrm{da-1})$, potasyum miktarının yüksek ( $\mathrm{K}_{2} \mathrm{O}: 94.00 \mathrm{~kg}$ $\mathrm{da}^{-1}$ ) ve organik maddenin orta (\% 2.26) olduğunu göstermiştir.

Samsun ili, Orta Karadeniz Bölgesi'nin ılıman iklim özelliklerini yansıtmaktadır. 
Mısır yetiştirme dönemine ait uzun yıllar ortalama sıcaklık $19.3^{\circ} \mathrm{C}$, toplam yağıș miktarı $493.5 \mathrm{~kg}\left(\mathrm{~m}^{2}\right)^{-1}$ iken, bu değerler 2018 yılında sirasıyla $20.6{ }^{\circ} \mathrm{C}$ ve $534.5 \mathrm{~kg}\left(\mathrm{~m}^{2}\right)^{-1}$ olmuştur. 2018 yılında Temmuz, Ağustos, Eylül ve Ekim ayları uzun yıllar vejetasyon ortalamasından daha yağışlı geçmiştir. Yetiştirme döneminde uzun yıllar nispi nem ortalaması \% 79.6 iken, 2018 yılında \% 78.4 olmuştur.

\section{Yöntem}

Araștırma Tesadüf Blokları deneme metodunda 3 tekrarlamalı olarak yürütülmüştür.

Deneme yeri sonbaharda pullukla işlenmiş, ekimden önce diskaro ve tırmık çekilerek tohum yatağı hazırlanmıştır. Ayrıca ekimden önce yabancı otlar için kimyasal mücadele uygulanmıştır. Ekim 26.04.2018 tarihinde, $70 \mathrm{~cm}$ aralıklarla açılan sıralara sıra üzeri $20 \mathrm{~cm}$ olacak şekilde elle yapılmıștır. Her parselde 5 m uzunluğunda 4 sıra yer almış, parseller arasında $1 \mathrm{~m}$ bloklar arasında ise $2.5 \mathrm{~m}$ boşluk bırakılmıştır.

Denemede $20 \mathrm{~kg} \mathrm{~N}$ da $^{-1}$ ve $10 \mathrm{~kg} \mathrm{P}_{2} \mathrm{O}_{5} \mathrm{da}^{-1}$ olacak şekilde gübreleme yapılmıştır. Azotun yarısı ve fosfor ekimle birlikte, azotun diğer yarısı ise tepe püskülü gösterme döneminde verilmiştir. Azot CAN (Calsiyum Amonyum Nitrat), Fosfor ise TSF (Triple Süper Fosfat) formunda verilmiştir.

Seyreltme-tekleme işlemi 20.05.2018 tarihinde, gerek yabancı otları kontrol etmek gerekse toprağın havalanmasını sağlamak amacıyla çapalama ve boğaz doldurma işlemi 30.05.2018 tarihinde yapılmıştır.

Denemede yabancı ot yoğunluğundaki artışa bağlı olarak çapa ve el ile parsellerdeki yabancı otlar gerek duyuldukça temizlenmiştir.

Denemede bitkilerirn suya ihtiyaç duyduğu dönemler de 30 Nisan 2018 tarihinde yağmurlama sulama, 21 Mayıs, 05 Haziran, 02 Temmuz ve 01 Ağustos 2018 tarihlerinde damla sulama yapılmıştır.

Araştırmada kullanılan mısır çeşitleri silaj verimi ve kalite özelliklerinin belirlenmesi amacıyla, her parsel ayrı ayrı taneler süt olum döneminde iken kenar tesiri ayrıldıktan sonra hasat edilmiştir.

Araştırmada yeșil ot verimi ( $\left.\mathrm{kg} \mathrm{da}^{-1}\right)$, sap/ bitki oranı $(\%)$, kuru madde verimi $\left(\mathrm{kg} \mathrm{da}^{-1}\right)$, ham protein oranı (\%), NDF (nötral detergent fiber), ADF (asit detergent fiber) gibi özellikler incelenmiştir. Ham protein analizi, öğütülmüș örneklerde NIRS cihazında mısır silajı kalibrasyon seti kullanılarak belirlenmiştir. ADF ve NDF analizleri ise Ankom cihazında (Ankom 220 fiber sistem) Van Soet ve ark..(1991)'nın bildirdiği yönteme göre yapılmıştır.
Elde edilen ADF ve NDF oranları kullanılarak aşağıdaki eşitlik yardımıyla (Önal Aşcı ve Acar, 2018) nisbi yem değeri (NYD) hesaplanmıştır.

$$
\begin{aligned}
& \text { NYD }=(\% \text { SKM }) \times(\% \text { KMT }) / 1,29 \\
& \% \text { SKM }=88,9-(0,779 \times \% \text { ADF }) \\
& \% \text { KMT }=120 / \% \text { NDF }
\end{aligned}
$$

Araştırma sonucunda elde edilen veriler SPSS22.0 istatistik paket programı kullanılarak tesadüf blokları deneme desenine göre varyans analizine tabi tutulmuştur. Önemlilik gösteren ortalamalar arası farklılıkların karşılaştırılmasında Duncan çoklu karşılaştırma testi kullanılmıştır.

\section{Bulgular ve Tartışma}

Yapılan varyans analizi sonucunda, denemede kullanılan mısır çeşitlerinin yeşil ot ve kuru madde verimleri-bakımından istatistiki olarak farksız ( $p>0.05$ ) olduğu belirlenmiştir (Çizelge 2). Çizelge 2' de görüldügü gibi en yüksek yeşil ot verimi 11077.0 kg da-1 ile DKC-955 çeşidinde belirlenirken, en düşük yeşil ot verimi $7242.7 \mathrm{~kg} \mathrm{da}^{-1}$ ile $36 \mathrm{~K} 61$ çeşidinde belirlenmiş, aralarındaki farklılıklar istatistiksel olarak önemli olmamıştır.

Değişik araştırıcılar mısır üzerine yaptıkları çalışmalarında yeşil ot veriminin $2675-10610 \mathrm{~kg} \mathrm{da}^{-1}$ arasında değiștiğini bildirmișlerdir (Aydın ve Albayrak, 1995; Aydın ve Uzun, 1995; Yllmaz ve ark., 1999; Özaslan ve Sevimay, 2006; Yıldız ve ark., 2017; Han, 2016; Ergül, 2008; Yozgatlı ve ark., 2019; Öner ve ark.,2011; Erdoğdu ve Altınok, 2003; Öner ve Güneş, 2019; Çaçan ve İşikten, 2019; Olgun, 2011). Çalışmamızda incelediğimiz mısır çeşitlerinin yeşil ot verim değerleri diğer araştırmalara göre yüksek bulunmuştur. Verimlerin 7 242.7-11 $077.0 \mathrm{~kg} \mathrm{da}^{-1}$ arasında değişiklik göstermesi doğru çeşitler kullanıldığında yeșil ot veriminin artabileceğini göstermiştir. Ülkemizde silajlık mısır yetiştiriciliği açısından iklim şartlarımızın uygunluğu göz önüne alındığında FAO'nın sınıflandırmasına göre 650-700 grubunda yer alan çeşitler kullanılmalıdır.

Denemede silajlık olarak tescilli çeşitlerin ekiminin yapılmasının büyük fayda sağladığı kanaatindeyiz. Ayrıca denemede elde edilen yeşil ot değerleriyle, diğer araştırıcıların değerlerindeki farklılıkların; kullanılan çeşitlerin farklı verim potansiyeline sahip olmasından, denemelerin yürütüldüğü yıllardaki iklim ve toprak özelliklerinden, uygulama ve 
yetiștirme tekniklerinin farklı olmasından kaynaklanmış olabileceği düşünülmektedir.

Araștırmada en düșük kuru madde verimi 3017.0 kg $\mathrm{da}^{-1}$ ile $36 \mathrm{~K} 61$ çeşidinde belirlenirken, en yüksek kuru madde verimi $3525.7 \mathrm{~kg} \mathrm{da}^{-1}$ ile HIDO çeşidinde belirlenmiş, çeşitler arasındaki farklılıklar istatistiksel olarak önemli olmamıştır (Çizelge 2).

Yaptıkları çalışmalarda, İptaş ve ark. (1997) kuru madde veriminin $2002.30-2634.90 \mathrm{~kg} \mathrm{da}^{-1}$, Güneş (2004) 2 193.43-2 655.20 kg da-1, Karayiğit (2005) 2 721-2 $226 \mathrm{~kg} \mathrm{da}^{-1}$, Ergül (2008) $1998-3028 \mathrm{~kg} \mathrm{da}^{-1}$,
Çaçan ve İşikten (2019) 2 078-2 $514 \mathrm{~kg} \mathrm{da}^{-1}$, Erdoğdu ve Altınok (2003) $1957-2621 \mathrm{~kg} \mathrm{da}^{-1}$ ve Öner ve Güneş (2019) 1 758.41-2 153.43 kg da-1 arasında değiştiğini bildirmişlerdir. Çalışmamızda belirlediğimiz kuru madde verimi ile ilgili değerlerin bu araştırıcıların bildirdiği sonuçlardan daha yüksek olduğu görülmektedir. Araştırma sonuçları arasındaki farklılıklar muhtemelen kullanılan çeşit, araştırmaların yürütüldüğü ekoloji, hasat zamanı ve uygulanan yetiştirme tekniklerindeki farklılıklardan kaynaklanmıştır.

Çizelge 2. Mısır çeşitlerinin yeșil ot ve kuru madde verimi ile sap/bitki oranlari ait ortalamaları

\begin{tabular}{lccc}
\hline Çeşitler & Yeşil ot verimi $\left(\mathrm{kg} \mathrm{da}^{-1}\right)$ & $\begin{array}{c}\text { Kuru madde verimi }(\mathrm{kg} \\
\left.\mathrm{da}^{-1}\right)\end{array}$ & \begin{tabular}{c} 
Sap/bitki oranı $(\%)^{*}$ \\
\hline 30 B 74
\end{tabular} \\
36 K 61 & 9963.3 & 3059.0 & $43.2 \mathrm{ab}$ \\
72 MAY 80 & 7242.7 & 3017.0 & $37.4 \mathrm{bc}$ \\
RX-9292 & 8919.3 & 3446.3 & $40.3 \mathrm{bc}$ \\
AGA & 7857.0 & 3222.3 & $39.9 \mathrm{bc}$ \\
DKC-955 & 9799.3 & 3054.3 & $40.2 \mathrm{bc}$ \\
HIDO & 11077.0 & 3479.0 & $42.1 \mathrm{ab}$ \\
OTELLO & 9758.0 & 3525.7 & $34.9 \mathrm{c}$ \\
RESERVE & 7336.0 & 3094.0 & $47.5 \mathrm{a}$ \\
SAMADA-07 & 8211.0 & 3290.0 & $35.1 \mathrm{c}$ \\
\hline Genel ortalama & 9818.7 & 3168.7 & $42.8 \mathrm{ab}$ \\
\hline \% VK & 8998.2 & 3235.6 & 40.4 \\
\hline
\end{tabular}

*Aynı harfle gösterilen ortalamalar arasında $\mathrm{P}<0.05$ olasılıkla farklılık yoktur.

Araştırmaya alınan mısır çeşitlerinin sap/bitki oranına ait ortalama değerler Çizelge 2'de verilmiştir. Varyans analizi sonucuna göre, sap/bitki oranı bakımından çeşitler arasındaki fark istatistiksel olarak önemli $(\mathrm{P}<0.05)$ bulunmuştur. Çalışmada en düşük sap/bitki oranı \% 34.9 ile HİDO çeşidinden elde edilmiştir. En yüksek sap/bitki oranı ise \% 47.5 ile OTELLO çeşidinde belirlenmiş, 30 B 74 (\% 43.2), SAMADA-07 (\% 42.8) ve DKC-955 (\% 42.1) çeşitleri ile aynı istatistiki grup içerisinde yer almıştır. Elde ettiğimiz sap/bitki oranı değerleri; ( $\%$ 44.93-56.20) Ergül (2008), (\% 48.8-53.1) Çaçan ve İşikten (2019)'in araştırma sonuçlarından düşük bulunurken, (\% 28.1-43.6) Akdeniz ve ark. (2003)'nın sonucundan yüksek bulunmuştur. Sap/bitki oranın düşük olması nedeniyle HIDO ve RESERVE çeşitleri değerli bulunmuştur. Düşük sap/bitki oranı toplam kaba yemin içinde yaprak ve koçan ağırlığının artması anlamına gelmektedir. Bitkilerde yem kalitesi bakımından bitki organları arasında kalite farklılıklarının olduğu bilinmektedir. Yapraklar gövdeye göre daha kalieti yem üretmektedirler (Önal Așcı ve Acar, 2018). Aynı zamanda mısır bitkisinde koçan tohumların bulunduğu organ olması sebebiyle koçan ağırlı̆̆ının artması, dolaylı olarak bitkide tohum ağırlığının arttığını göstermektedir. Tohumlar karbonhidrat olarak nişasta depo ettiklerinden, tohum ağırlığının artması toplam yemin içinde hızlı parçalanan karbonhidrat miktarının artması anlamına gelmektedir. Nişasta silaj esnasında Laktik asit bakterilerinin hızlı çoğalmasını sağlayarak, silaj Ph'nın kısa sürede 4.0'ün altına düşmesini, dolayısıyla kalitesinin yüksek olmasını sağlamaktadır.

Kaba yem üretiminde yüksek verim kadar kalite de önemlidir. Yemin kalitesini belirlemek amaciyla genellikle ham protein, ADF ve NDF oranları incelenmektedir. Araştırmada belirlenen ham protein, ADF ve NDF oranlarına yapilan varyans analizi sonucunda, söz konusu özellikler bakımından çeşitler arasındaki farklılık istatistiksel olarak önemli $(\mathrm{p}<0.01)$ bulunmuştur. 
Çalışmada en düşük ham protein oranı \% 5.01 ile AGA çeşidinden elde edilmişken, en yüksek ham protein oranı \% 9.48 ile RX-9292 çeşidinden elde edilmiş ve 36 K 61 (\% 9.40) çeşidi ile arasındaki fark istatistiksel olarak önemsiz bulunmuștur (Çizelge 3). Söz konusu bu iki çeşit ile diğer çeşitler arasındaki farklar ise önemli olmuştur. Araştırmada elde ettiğimiz ham protein oranı değerleri, \% 6.16-8.61 ile Yıldız ve ark. (2017), \% 4.68-6.87 ile Ergül (2008), \% 7.63-9.32 ile Öner ve Güneş (2019), \% 6.5- 8.19 ile Han (2016), \% 7.70-8.48 ile Olgun (2011), \% 5.52-8.17 ile Akdeniz ve ark. (2003), \% 6.92-9.09 ile Başaran ve ark. (2017)'nın sonuçlarından yüksek bulunurken; \% 9.97-11.13 ile Çiğdem ve Uzun (2006) ve \% 5.11-
11.16 ile Balmuk (2012)'nin sonuçlarından düşük bulunmuştur.

Ham protein oranları; çeşitlerin genetik özelliğine, hasat zamanına, uygulanan yetiștirme tekniklerine, yetiștirildiği yerin iklim ve toprak özelliklerine, yetiştirildiği vejetasyon dönemine, ekim zamanına, uygulanan azotlu gübre miktarına göre değişiklik göstermiş olabilir. Silajlık mısırda ham protein oranı önemli bir kalite unsurudur ve bu oranın yüksek olması istenilmektedir. $\mathrm{Bu}$ özellik açısından çalışmamızda RX-9292 ve 36 K 61 çeşitleri öne çlkmıştır.

Çizelge 3. Mısır çeşitlerinin ham protein, ADF ve NDF oranına ait ortalamaları (\%)

\begin{tabular}{lcccc}
\hline Çeșitler & Ham protein orani** & ADF** & NDF** & NYD \\
\hline 30 B 74 & $8.65 \mathrm{~b}$ & $35.07 \mathrm{bc}$ & $56.00 \mathrm{a}$ & 102.4 \\
36 K 61 & $9.40 \mathrm{a}$ & $34.99 \mathrm{bc}$ & $44.17 \mathrm{ef}$ & 130.0 \\
72 MAY 80 & $6.63 \mathrm{c}$ & $34.50 \mathrm{bc}$ & $46.90 \mathrm{de}$ & 123.2 \\
RX-9292 & $9.48 \mathrm{a}$ & $34.17 \mathrm{c}$ & $44.99 \mathrm{def}$ & 129.0 \\
AGA & $5.01 \mathrm{~d}$ & $37.47 \mathrm{ab}$ & $48.57 \mathrm{~cd}$ & 114.4 \\
DKC-955 & $6.76 \mathrm{c}$ & $39.17 \mathrm{a}$ & $53.30 \mathrm{ab}$ & 102.0 \\
HIDO & $6.92 \mathrm{c}$ & $33.53 \mathrm{c}$ & $42.40 \mathrm{f}$ & 137.9 \\
OTELLO & $6.58 \mathrm{c}$ & $34.00 \mathrm{c}$ & $51.33 \mathrm{bc}$ & 113.3 \\
RESERVE & $6.90 \mathrm{c}$ & $34.00 \mathrm{c}$ & $48.13 \mathrm{~cd}$ & 120.8 \\
SAMADA-07 & $6.61 \mathrm{c}$ & $29.00 \mathrm{~d}$ & $48.00 \mathrm{cde}$ & 128.6 \\
\hline Genel ortalama & 7.29 & 34.59 & 48.38 & 120.1 \\
\hline \% VK & 2.97 & 4.89 & 4.29 & 4.82 \\
\hline
\end{tabular}

**Aynı sütunda aynı harfle gösterilen ortalamalar arasında $\mathrm{P}<0.01$ olasılıkla farklılık yoktur.

NDF: Nötral Detergent Fiber, ADF: Asit Detergent Fiber, NYD: Nisbi Yem Değeri

Çizelge 3 incelendiğinde görüleceği üzere en düşük NDF oranı \% 42.40 ile HİDO çeşidinden elde edilmiş olup bu çeşidi sırasıyla 36 K 61 ve RX-9292 çeşitleri izlemiştir.

Bitki organlarını farklı dokuların bir araya gelmesi sonucu oluştuğundan, organlarda bulunan dokuların miktarı ve çeşidi de farklı olmaktadır. Dokularda bulunan hücrelerin hücre duvarı bakımından farklılıklar bulunmaktadır. Genellikle yapraklarda ince hüvre duvarına sahip dokular gövdeye göre daha fazla miktarda bulunmaktadır (Önal Așcı ve Acar, 2018). NDF hücre duvarı miktarı hakkında bilgi verdiğinden sap/ bitki oranı düşük olan çeşitler (Çizelge 2) daha düşük NDF oranına sahip olmuştur.

En yüksek NDF oranı \% 56.00 ile 30 B 74 çeşidinde belirlenmiş, DKC-955 (\% 53.30) çeşidi ile aynı istatistiki grup içerisinde yer almıştır. Araştırmada elde ettiğimiz NDF değerleri \% 49-60 ile Öner ve ark. (2011), \% 57.5-73.85 ile Balmuk (2012), \% 53.79-
61.77 ile Han (2016), \% 50.53-60.40 ile Başaran ve ark. (2017), \% 50.57-57.43 ile Öner ve Güneș (2019)'in sonuçlarından düşük bulunmuşken, \% 51.6-52.0 ile Özata ve Kapar (2017)'nin sonucundan yüksek bulunmuștur. NDF hücre duvarı öğelerinin belirlenmesinde kullanılan selüloz, hemi-selüloz, lignin, ligninleșmiş proteinlerden meydan gelen lifli yapılardır (Kutlu, 2008). NDF değeri hayvanların yem alımında doğrıudan etkilidir. NDF oranı düştükçe, hayvanın yem alımı artar (Önal Așcı ve Acar, 2018).

ADF, NDF içerisinden hemi-selüloz çlkartılarak elde edilir. ADF, hayvanın enerji alımı ve yemin sindirilebilirliği hakkında fikir veren bir göstergedir (Kutlu, 2008). Başka bir deyişle yemde ADF oranı arttıkça sindirimi dolayısıyla kalitesi azalır. Araștırmada en düșük ADF oranı \% 29.00 ile SAMADA-07 çeșidinden elde edilmiștir. Araștırılan çeșitler içerisinde en fazla yaprak sayısına ve yaprak ağırlığına sahip olan çeşit Samada çeşididir (Data gösterilmemiştir). 
Daha önce de ifade edildiği gibi yaprakların ADF oranı gövdeden daha düşüktür. En yüksek ADF oranı \% 39.17 ile DKC-955 çeşidinde belirlenmiş, AGA (\% 37.47) çeşidi ile aynı istatistiki grup içerisinde yer almıştır. Elde ettiğimiz ADF değerleri \% 30.46-35.53 ile Han (2016), \% 31.30-37.47 ile Başaran ve ark. (2017), \% 30.2-32.5 ile Özata ve Kapar (2017), \% 25.61-30.80 ile Öner ve Güneş (2019)'in sonuçlarından yüksek bulunmuşken, \% 31-41 ile Öner ve ark. (2011), \% 31.25-43.29 ile Balmuk (2012)'un sonuçlarından düşük bulunmuştur. ADF ve NDF oranları kullanılarak hesaplanan nisbi yem değerleri (NYD) bakımından çeşitler arasında istatistiki olarak farklılı bulunmamakla ( $p>0.05)$ çeşitlerin nisbi yem değerleri 102.4.-137.9 arasında değișim göstermiștir. En yüksek NYD değeri 137.9 ile HIDO çeşidinde belirlenirken, endüșük NYD değeri 1202.0 ile DK-955 .eşidinde elde edilmiştir.
ABD'de geliștirilen kaliteli kaba yem standartları (Çizelge 4) ile araştırmada incelenen çeşitlerde belirlenen ham protein, ADF ve NDF oranları ile NYD değerleri karşılaştırıldığında, ham protein oranı bakımından 72 MAY 80 (\% 9.48), 36 K 61 (\% 9.40) ve 30 B 74 (\% 8.65) çeşitleri az kaliteli sınıfa girerken, diğer çeşitler kalitesiz sınıfa girmişlerdir.

NDF oranlarına bakıldığında HíDO (\% 42.40), 36 K 61 (\% 44.17) ve RX-9292 (\% 44.99) çeşitleri kaliteli (premium) sınıfta, DKC-955, 30 B 74 çeşitleri orta kaliteli sınıfta yer alırken, diğer çeşitler iyi kaliteli sınıfta yer almışlardır.

ADF oranlarında ise, SAMADA-07 en üst kalite (prime), DKC-955, AGA ve 30 B 74 iyi (good) kalite, diğerleri ise kaliteli (premium) sinıfında yer almışlardır.

Çizelge 4. Çiftlik hayvanları için kaba yem kalite standartları (Önal Aşcı ve Acar, 2018)

\begin{tabular}{ccccc}
\hline Kalite Standart & Ham Protein & ADF & NDF & NYD \\
\hline İlk (en üst kalite) & $>\% 19$ & $<\% 31$ & $<\% 40$ & $>151$ \\
1 (kalite) & $\% 17-19$ & $\% 31-35$ & $\% 40-46$ & $151-125$ \\
2 (iyi) & $\% 14-16$ & $\% 36-40$ & $\% 47-53$ & $124-103$ \\
3 (orta) & $\% 11-13$ & $\% 41-42$ & $\% 54-60$ & $102-87$ \\
4 (az) & $\% 8-10$ & $\% 43-45$ & $\% 61-65$ & $86-75$ \\
5 (kalitesiz) & $<\% 8$ & $>\% 45$ & $>\% 65$ & $<75$ \\
\hline
\end{tabular}

NDF: Nötral Detergent Fiber, ADF: Asit Detergent Fiber), NYD: Nisbi Yem Değeri

\section{Sonuç}

Samsun Çarşamba ekolojik koşullarında sulanarak ana ürün olarak yetiştirilen bazı silajlık mısır (Zea mays L.) çeşitlerinin verim ve kalite özelliklerinin belirlenmesi amacıyla yürütülen tek yıllık çalışma sonuçlarına göre, yeșil ot ve kuru madde verimi bakımından çeşitler arasındaki farklılık istatistiksel olarak önemli bulunmamış ve elde edilen verim sirasıyla 11077.0 - $7242.7 \mathrm{~kg} \mathrm{da}^{-1}$ ve 3525.7 - 3017.0 $\mathrm{kg} \mathrm{da}^{-1}$ arasında değişmiştir. Bununla birlikte elde edilen otun ham protein, ADF ve NDF oranı bakımından çeşitler arasındaki farkın çok önemli $(\mathrm{P}<0.01)$ olduğu belirlenmiştir.

Çalışma sonucunda verim, ham protein ve NDF değerleri birlikte değerlendirildiğinde RX-9292 ve 36 K 61 çeşitlerinin söz konusu bölge için diğer çeşitlerden daha uygun olduğu düşünülmektedir.

Kesin öneriler yapabilmek için bu çalışmaların bir kaç yıl, daha kapsamlı olarak yapılmasına ihtiyaç vardır.

\section{Kaynaklar}

Akdeniz, H., Yılmaz, İ., Antiç, N., \& Zorer, Ş. (2003). Bazı mısır çeşitlerinde verim ve yem değerleri üzerine bir araștırma. Yüzüncü Yıl Üniversitesi, Ziraat Fakültesi Dergisi, 14, 47-51.

Anonim, (2018). Mısır raporu-2018. http://www.zmo.org. tr/genel/bizden_detay.php? kod=30187\&tipi=17\& sube $=0$.

Aydın, İ., \& Albayrak, S. (1995). Samsun ekolojik şartlarında ikinci ürün olarak yetiştirilen bazı bitkilerin farklı biçim zamanlarında ot ve ham protein verimleri üzerine bir araștırma. OMÜ Ziraat Fakültesi Dergisi, 10, 71-81.

Aydın, İ., \& Uzun, F. (1995). Samsun ekolojik şartlarında II. Ürün olarak yetiştirilen silajlık mısırın kuru ot ve ham protein verimi üzerine sıklık ve biçim zamanının etkisi. OMÜ Ziraat Fakültesi Dergisi, 10, 15-21. 
Balmuk, Y. (2012). Konya Yunak koşullarında ikinci ürün olarak yetiştirilebilecek silajlık mısır çeşitlerinin verim ve verim özelliklerinin belirlenmesi. Yüksek Lisans Tezi. Gazi Osman Paşa Üniversitesi. Fen Bilimleri Enstitüsü. Tokat.

Başaran, U., Gülümser, E., Çopur Doğrusöz, M., Mut, H., \& Şahin, H. (2017). Farklı silajlık mısır çeşitlerinin hamur olum döneminde silaj ve tane özelliklerinin belirlenmesi. KSÜ Doğa Bilimleri Dergisi, 21 (Özel Sayl), 1-5.

Çaçan, E., \& İşikten, S. (2019). Bingöl ili ekolojik koşullarında bazı silajlık mısır çeșitleri için uygun ekim zamanının belirlenmesi. Türkiye Tarımsal Araştırmalar Dergisi, 6, 39-49.

Çete, N., \& Sarıcan, C. (1998). Silajlık yem bitkileri üretim ve silaj yapımı. U.S. Grains Council.

Çevik, M. (2012). Mısır Raporu.Ulusal Hububat Konseyi, Konya.

Çiğdem, S., \& Uzun, F. (2006). Samsun ili taban alanlarında ikinci ürün olarak yetiştirilebilecek bazı silajlık sorgum ve mısır çeşitleri üzerine bir araştırma. $O M \ddot{U}$ Ziraat Fakültesi Dergisi, 21, 14-19.

Erdoğdu, İ., \& Altınok, S. (2003). Silajlık olarak yetiştirilen bazı atdişi hybrid mısır (Zea mays indentata Sturt.) çeșitlerinin bitkisel özellikleri ve yem verimleri. Tarım Bilimleri Dergisi, 9, 170-173.

Ergül, Y. (2008). Silajlık mısır çeşitlerinin önemli tarımsal ve kalite özelliklerinin belirlenmesi. Yüksek Lisans Tezi, Selçuk Üniversitesi, Fen Bilimleri Enstitüsü, Tarla Bitkileri Anabilim Dalı, Konya.

Güneș, A. (2004). Karaman ekolojik koşullarında silajlık hibrit misır çeşitleri ve sorgum-sudan otu melezlerinin ikinci ürün olarak yetiștirme imkanlarının belirlenmesi. Yüksek Lisans Tezi. S. Ü. Fen Bilimleri Enstitüsü. Tarla Bitkileri Anabilimdalı. Konya.

Han, E. (2016). Bazı mısır çeşitlerinin dane verimleri ile silaj ve kalite özelliklerinin belirlenmesi. Yüksek Lisans Tezi, Ordu Üniversitesi, Fen Bilimleri Enstitüsü, Tarla Bitkileri Anabilim Dalı, Ordu.

İptaş, S., Yılmaz, M., Öz, A., \& Avcıoğlu, R. (1997). Tokat ekolojik şartlarında silajlık mısır, sorgum tür ve melezlerinden yararlanma olanakları. Türkiye I. Silaj Kongresi İstanbul. Hasat Yayıncılık, 97-105.

Karayiğit, İ. (2005). Farklı olgunluk dönemlerindeki bazı melez misır çeşitlerinin silaj kalitesi üzerine araștırmaları. Yüksek Lisans Tezi. Kahramanmaraş
Sütçü İmam Üniversitesi. Fen Bilimleri Enstitüsü. Tarla Bitkileri Anabilim Dalı. Kahramanmaraş.

Kılıç, A. (1986). Silo Yemi. Bilgehan Basımevi. Bornova, İzmir.

Kutlu, H.R. (2008). Yem değerlendirme ve analiz yöntemleri (Ders notu). Çukurova Üniversitesi. Ziraat Fakültesi. Zootekni Bölümü. Adana.

Olgun, F. (2011). Silajlık melez mısır çeşitlerinin farklı hasat zamanının verim, verim unsurları ve kalite üzerine etkisi. Yüksek Lisans Tezi, Selçuk Üniversitesi, Fen Bilimleri Enstitüsü, Tarla Bitkileri Anabilim Dalı, Konya.

Önal Așcl, Ö., \& Acar, Z. (2018). Kaba yemlerde kalite. TMMOB Ziraat Mühendisleri Odası Yayınları. ISBN978-605-01-1227-6.

Öner, F., Aydın, İ., Sezer, İ., Gülümser, A., Özata, E., \& Algan, D. (2011). Bazı silajlık mısır çeşitlerinde verim ve kalite özelliklerinin belirlenmesi. Türkiye 9. Tarla Bitkileri Kongresi, Bursa.

Öner, F., \& Güneș, A. (2019). Bazı mısır (Zea mays L.) çeșitlerinin silajlı verim ve kalite özelliklerinin belirlenmesi. Tekirdağ Ziraat Fakültesi Dergisi. 16, 42-50.

Öz, A., Kapar, H., \& Dok, M. (2017). Karadeniz Tarımsal Araştırma Enstitüsü Yayınları. http://arastirma.tarim.gov.tr/ktae/Belgeler/brosu rler/Mısır\%20Tarımı.pdf

Özaslan, A., \& Sevimay, C. (2006). Arpa ve buğday hasadından sonar bazı yem bitkilerinin ikinci ürün olarak yetiștirilme imkanları. Ankara Üniversitesi Ziraat Fakültesi Tarım Bilimleri Dergisi, 13, 101-107.

Özata, E., \& Kapar, H. (2017). Nitelikli saf hatlardan elde edilen silajlkık hibrit mısır çeşit adaylarının verim ve kalite özelliklerinin belirlenmesi. Tarla Bitkileri Merkez Araştırma Enstitüsü Dergisi, 26, 161-168.

Phipps, R., \& Wilkinson, M. (1985). Maize Silage. Chalmcombe, Publications, 13. High Woods Drive, Mar-low Bottom. Morlown Bucks. SL 73PU. September. 48 p.

Yıldız, H., İlker, E., \& Yıldırım, A. (2017). Bazı silajılı mısır (Zea mays L.) çeşit ve çeşit adaylarının verim ve kalite özelliklerinin belirlenmesi. Süleyman Demirel Üniversitesi, Ziraat Fakültesi Dergisi. 12, 81-89.

Yılmaz, Ş., Gözübenli, H., Can, E., \& Ateş, İ. (1999). Hatay koşullarında II. Ürün olarak yetiştirilebilecek silajlık mısır çeșitlerinin belirlenmesi üzerine bir araștırma. Türkiye 3. Tarla Bitkileri Kongresi (15-18 
Kasım), 3. cilt. Chayır Mera Yem Bitkileri ve Yemeklik Yozgatlı, O., Bașaran, U., Gülümser, E., Mut, H., Copur \& Tane Baklagiller, 295-299, Adana. Doğrusöz, M. (2019). Yozgat ekolojisinde bazı mısır çeşitlerinin morfolojik özellikleri, verim ve silaj kaliteleri. KSÜ Tarım ve Doğa Dergisi 22,170-177. 